\title{
リモートセンシングにより得られる 近畿地方北西部地域の応力場
}

向山広・木村強・茂木透

(昭和 61 年 6 月 19 日受理)

\section{The Stress Field Derived from Remote Sensing in the Northwest Kinki District, Southwest Japan}

\author{
Hiromu Mukaiyama, Tsuyoshi Kimura and Tohru Mogi \\ Faculty of Engineering, Kyushu University
}

(Received June 19, 1986)

The study using the slope-shaded map and lineament map from Landsat images reveals that the Kinki district consists of several geologic blocks resembling a mosaic. The main lineaments are divided into four patterns by their direction and geological significance: they are N-S, E-W, NE-SW, NW-SE and sometimes cut each other. Some of them show a relatively good agreements with the distribution of active faults and linear distribution of microearthquake epicenters.

Some large lineaments are located in the boundary of geologic blocks. Their distribution patterns seem to indicate that this district has been under an $\mathrm{E}-\mathrm{W}$ compressive force at least throughout the Quaternary.

\section{$\S 1$. 緒言}

近年，ランドサット画像を中心として多種の図形から種々の地形情報を抽出して，それと各 種の地学情報とを対比して地質構造の推定が行われるようになつた。この手法は比較的小縮尺 の広域にわたる図形を使用して，調査地域のみならずその周囲の地域をも含めて広い地域を短 時間に検討することができるのが大きな特徵であり，精細な問題は他の調査によるにしても対 象地域を大局的に評価できる利点をもつている，したがつて，対象地域から大規模な構造に関 する問題点を迅速に抽出して調査の焦点をしぼることが容易になり, 調査速度も速めることが できる.

今回は, 地震観測網が整備され, また, 活断層分布等の多種の地質学的・地球物理的データ の密度の比較的高い近畿地方北西部地域を対象にして，震央分布や活断層の分布と地形情報と の対比を行うと共に，それらをもとに新第三紀以降に近畿地方に働いていた応力の方向の推定 も行つた. その結果, この地域で地学情報と地形情報が良い対応を示すと共にリニアメントか ら得られた応力場が従来の研究成果と良い調和がみられた。したがつて，この手法を用いて他 
の地域の地質構造や応力場を推定することが可能と考えられる.

\section{§2.リニアメントの抽出}

\section{2-1. 基礎となる各種図形}

今回の研究では, 主としてランドサット 2 拈よび 3 号の各 MSS 画像と, LANDSAT ATLAS: JAPAN [日本放送出版協会 (1984)] の 80 万分の 1 画像を使用した.

これらの図を観察しながら, 細かい地形の特徴を識別し, 斜面の規模や傾斜の程度を読み取 り，東および南向きの急斜面を手作業で直接黒く塗りつぶすことによつて，特定の方位を持つ 斜面の形を強調した。 このような図を斜面強調図と呼び Fig. 1 に示す.この図は東に向いた 斜面（走向が N-S ないし NE-SW）抢よび南に向いた斜面（走向が E-W ないし NW-SE） を強調したので, 限られた方向の光による陰で示されるような極端な方向性の強調を避けるこ とができる．ランドサット画像上で入射光の方位に近い方向に延びる斜面や谷は，本来ならば 陰となる斜面の占める面積が小さくなりがちで識別しにくい，ところが，上記方法では光と平 行な斜面をその形や大きさ等について検討することによつて，それも強調することができる. また，入射光にほぼ直交する方向をもつ多くの斜面の分布状態に注目すると，それらの配列を

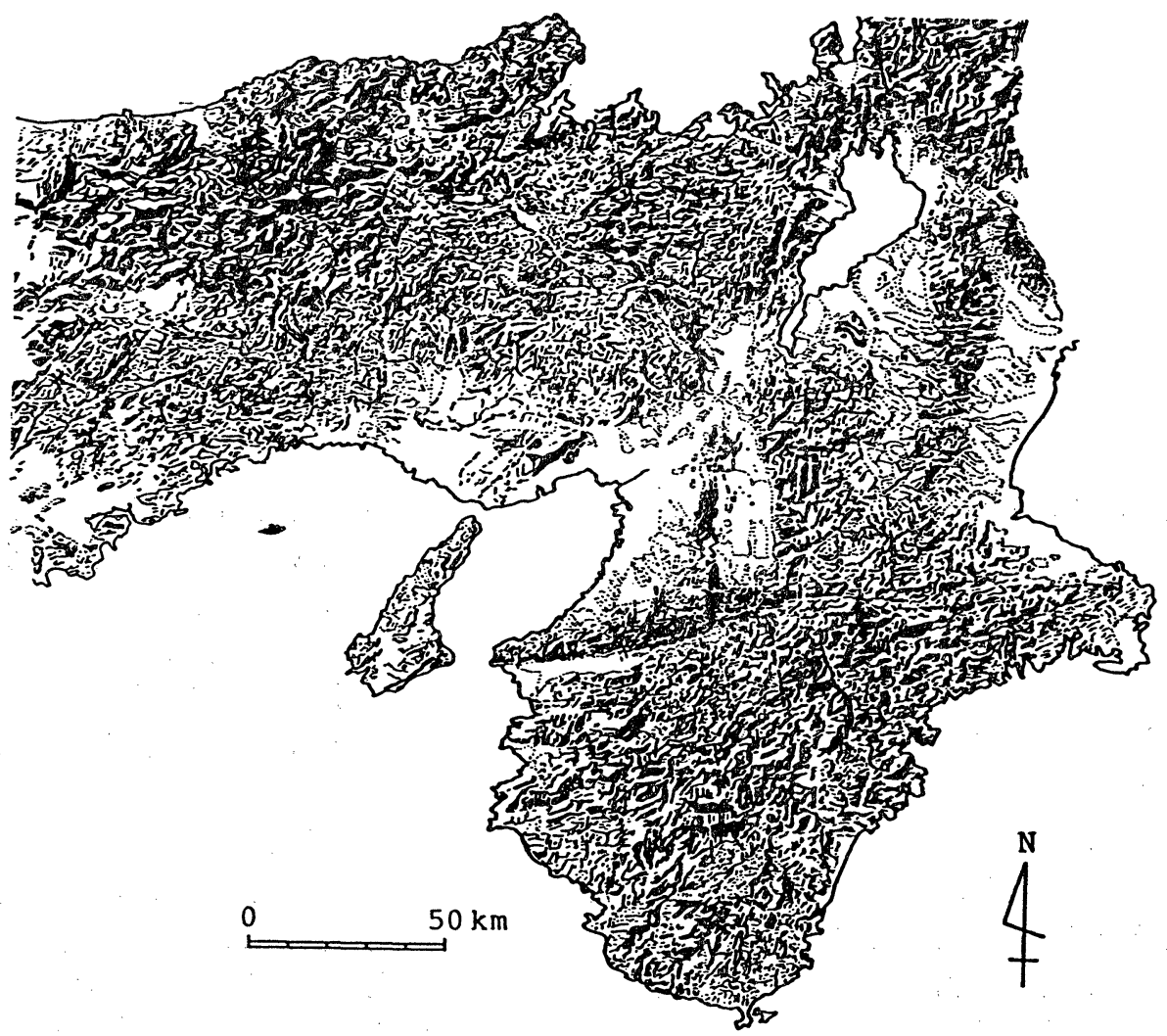

Fig. 1. Slope-shaded map detected from Landsat images. The east to south facing slopes are shaded. 


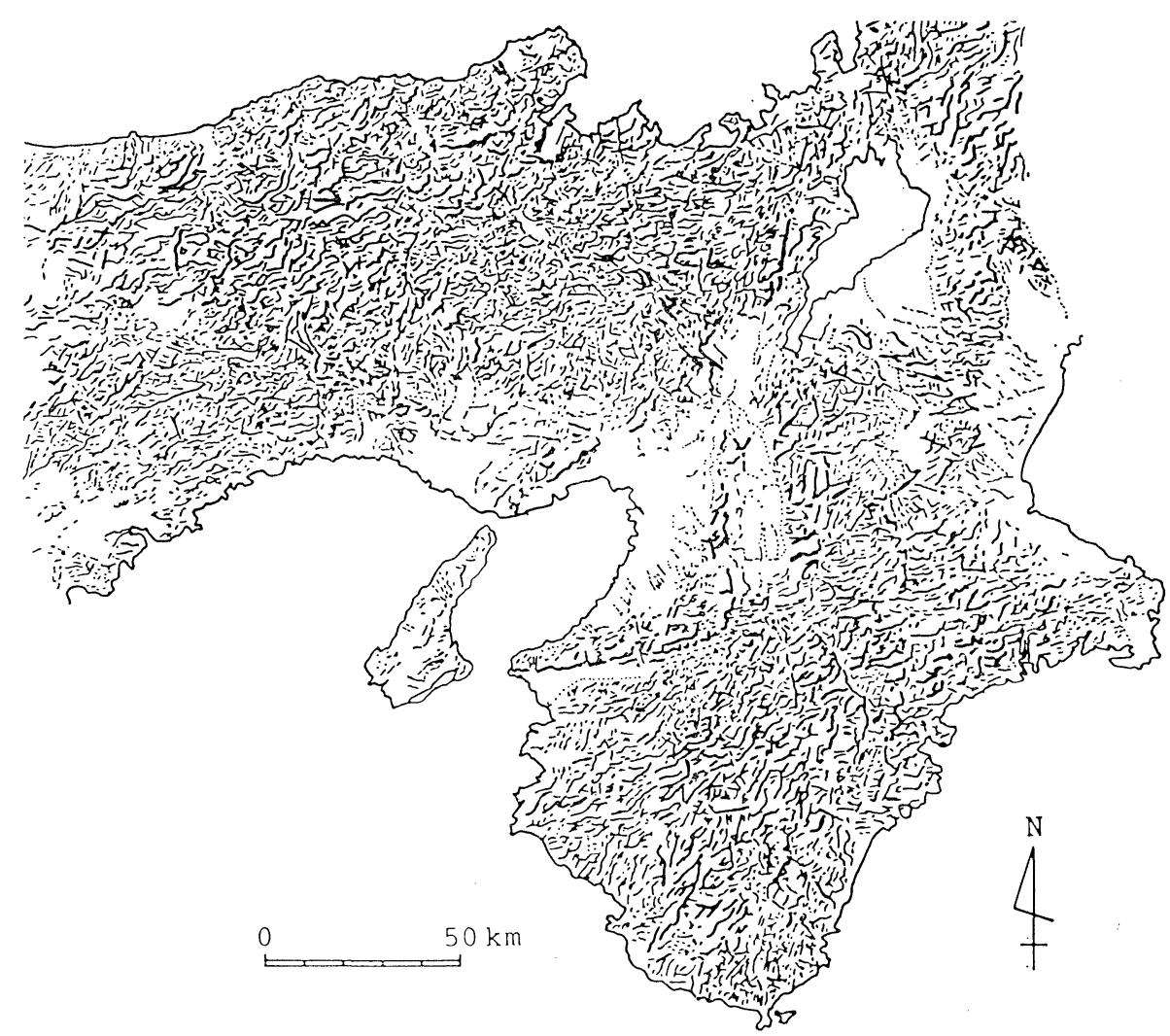

Fig. 2. Small scale lineaments detected from Fig. 1.

規制する別の方向をるつ斜面や谷を，間接的に強調することになる。

Fig. 2 は, Fig. 1 の斜面の脚部にある谷をリニアメントとして表したものである. 図に示 されるように近畿地方にはほぼ N-S，E-W， NE-SW，NW-SE の 4 方向に伸びる主要なリ ニアメントが認められる．細かいリニアメントの走向は必ずしも一様ではないが，同じような 方向のものが集合してひとつのブロックを構成していると考劣ることができる．また，細かい リニアメントが集中して幅の狭い帯を作ることもある．このようなブロックの境界のらちで比 較的長いもののみを抽出したものが Fig. 3 である.これは, ランドサット画像から直接抽出 された大規模なリニアメント [向山・他 (1986)] のように短いものは含まないけれども，両者 の全体的傾向は，良い調和を示す．これらの方向性にも上記 4 方向の走向が認められる. 図に 示されるように, リニアメントの配列や走向方向によつて近畿地方は(1)中央構造線以南, (2)花 折一生駒断層, 中央構造線, 敦賀湾一伊勢湾線で囲まれる地域, および(3)花折一生駒断層以西 の 3 つの地域に区分される.

(1)の地域の E-W と NE-SW 方向のリニアメントはこの地域の古第三紀以前の地層の一般 走向およびその断層に沿う地形を表しているが， N-S 系のものはこれらを横切つていると共 に，中央構造線に沿う $\mathrm{E}-\mathrm{W}$ 系のリニアメントを乱して拈り，一部ではそれを切ることもあ る. また， N-S 系自身も E-W 系によつて乱されている. (2)の地域には N-S 系のリニアメ 


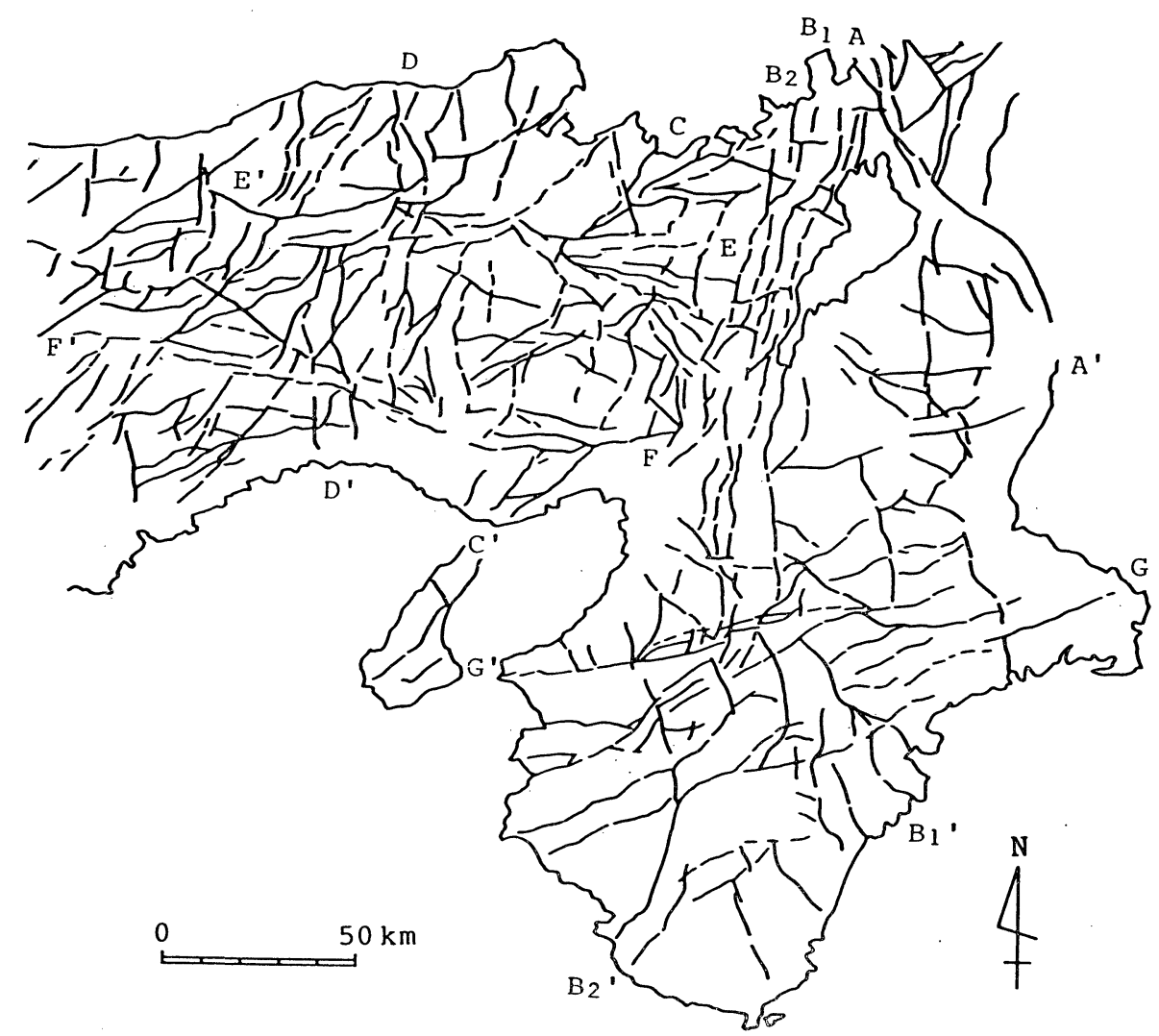

Fig. 3. Large scale lineaments detected from Fig. 1. Areas shown by simbols A $A^{\prime}$ to $G \sim G^{\prime}$ are the zones where many lineaments are concentrated.

ントが卓越するが，その一部は中央構造線を横切つて11の地域にも延びている。しかし，その 分布や延長は中央構造線付近で変化している。また， E-W 系のものも認められる. (3の地域 は WNW-ESE ないし NW-SE および NE-SW 系のリニアメントが卓越し, Fig. 3 の C 〜 C 和よび D〜D' の N-S 系のものはこれらによつてその連続性を乱されている.

\section{2-2. 近畿地方の地形とリニアメントとの関連}

Fig. 4 には, 国土地理院の 50 万分の 1 地形図から作成した等高線図に前述のリニアメン トを重ねたものが示してある.

この図によると, (1)の地域では $\mathrm{B}_{1} \sim \mathrm{B}_{1}{ }^{\prime}$ と $\mathrm{B}_{2} \sim \mathrm{B}_{2}{ }^{\prime}$ の $\mathrm{N}-\mathrm{S}$ 系のリニアメントに㣣まれた 地域は, その両側の標高 $200 \mathrm{~m}$ 前後の地域に比べて高い山地が分布し, 標高 $1200 \sim 1800 \mathrm{~m}$ の山々が南北に 2 列に並んでいる. したがつて, (1)の地域は, 地形的には南北に延びる中央の 高い山地と両側のやや標高の低い地域との 3 つのブロックに区分され，この境界に主要なリニ アメントが観察される.

(2)の地域の N-S 系リニアメントは主に急斜面をもつ山地の縁拉よびその中に発達している ものである. 例えば, $\mathrm{A} \sim \mathrm{A}^{\prime}$ は伊吹山地の西麓と養老山地の東麓に沿らものであり, 鈴鹿山 脈の両側にも同様のものが認められる.さらにこの地域の西部の比良, 生駒, 金剛山地等では, 


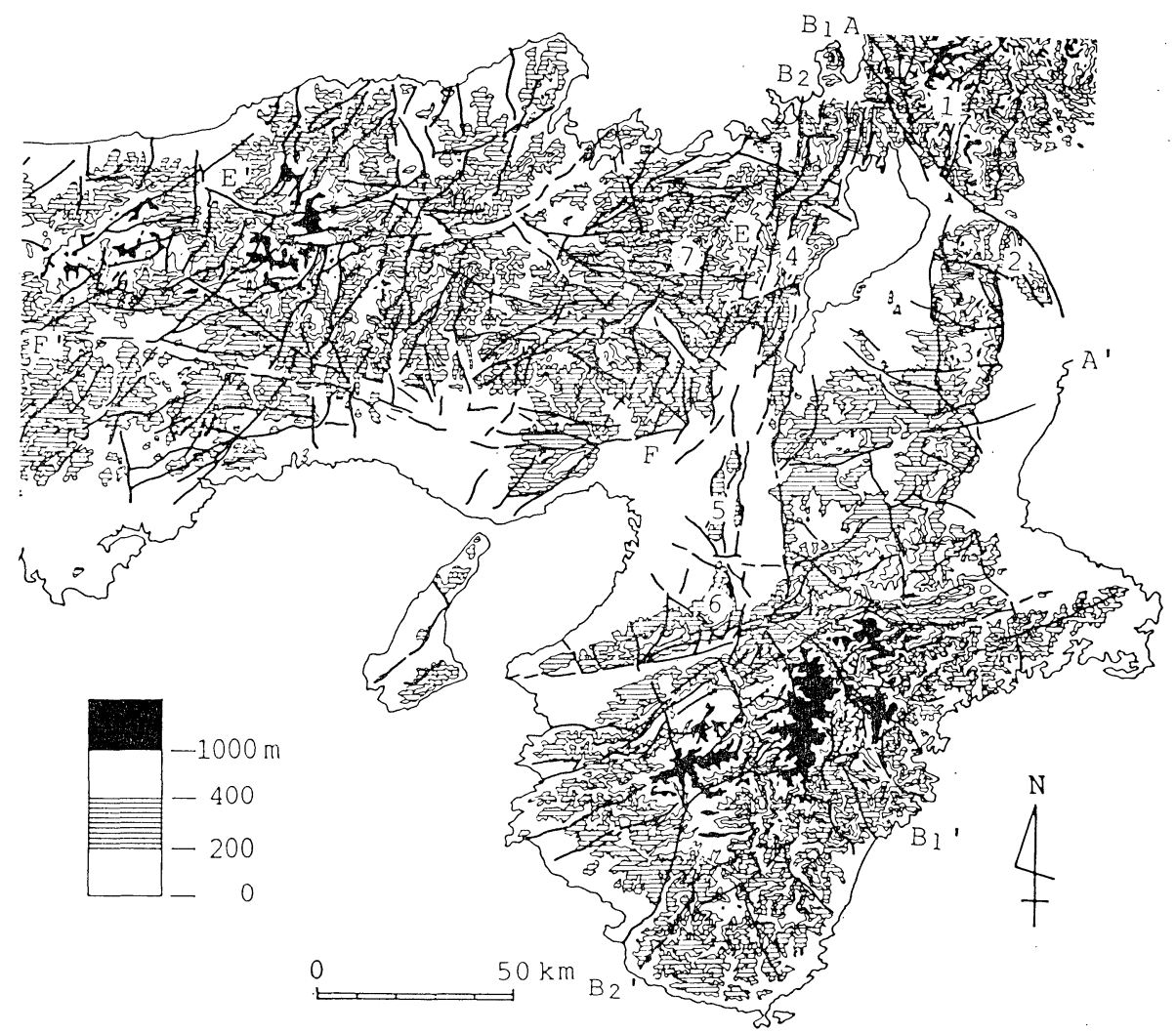

Fig. 4. Contour line map, together with large scale lineaments in Fig. 3. Level of 200 to $400 \mathrm{~m}$ is striped. 1: Ibuki Mt., 2: Yohroh Mt., 3: Suzuka Mts., 4: Hira Mt., 5: Ikoma Mt., 6: Kongoh Mt. and 7: Tanba Mt.

それに沿う多数の $\mathrm{N}-\mathrm{S}$ 系リニアメント $\mathrm{B}_{1} \sim \mathrm{B}_{1}{ }^{\prime}$ や $\mathrm{B}_{2} \sim \mathrm{B}_{2}{ }^{\prime}$ が発達し, これらの山地の両側 には南北飞延びる低地が分布している。すなわち, 高地と低地をなす地塊が交互に分布するこ とになる。

(3)の地域の中央部には，潘济東西に延びる丹波山地やその西に広がる山地がありその中には 標高 500 1500 m 飞達する山々が核ぼ東西に並んでいる. 上記の山地は $\mathrm{E}-\mathrm{W}$ 系のリニアメ ント $\left(\mathrm{E} \sim \mathrm{E}^{\prime}\right.$ および $\left.\mathrm{F} \sim \mathrm{F}^{\prime}\right)$ に㣣まれた地域であり， $\mathrm{F} \sim \mathrm{F}^{\prime}$ の南側はほとんど標高 $200 \mathrm{~m}$ 以下の低地である。.また， $\mathrm{E} \sim \mathrm{E}^{\prime}$ の北側も同様の低地を構成しているが，この地区には後述 のように火山岩が広く分布し，一部標高の高いところもあるけれども，その厚みを取り去ると 基盤岩類の表面の標高はかなり低いものとなる．このように近畿地方北西部にはほぼ WNW$\mathrm{ESE}$ 方向に伸びる 3 列のブロックがあり，その中央のものの標高が高い，そしてこのブロッ クの境界にそれと同方向に伸びるリニアメント群が観察される. このブロックはさらに N-S 系, NE-SW 系, NW-SE 系等のリニアメントによつて細かく区分される. 


\section{§3. 地質資料とリニアメントの対比}

\section{3-1. 火山岩の分布とリニアメント}

近畿地方の中新世以降の火山岩の分布を Fig. 5 に示す.この図によると中新世前〜中期の 火山活動は, $\mathrm{N}-\mathrm{S}$ 系のリニアメント群 $\mathrm{B}_{1} \sim \mathrm{B}_{1}{ }^{\prime}$ および $\mathrm{B}_{2} \sim \mathrm{B}_{2}{ }^{\prime}$ に沿う(1)の地域の 中央部の 高地帯と(3)地域の北側のブロック中にのみ起こつている. (1)の地域の中央高地の活動は, $\mathrm{N}-\mathrm{S}$ 系のリニアメントに沿つて抒り，その活動を引き起こした断裂の存在が推定される. (3) の地域の北側のブロックでは中新世以降完新世までの各時期の火成活動が活発であつた。 これ 以外はすべて古第三紀以前の火成岩または堆積岩から構成されている．またこのブロックでは， その南端の境界に明瞭なりニアメントが見られ, ブロックはこれに沿つて延びている。

\section{3-2. 断層とリニアメント}

Fig. 6 に本地域で報告されている活断層 [活断層研究会 (1980)］和よび日本地質アトラス [地質アトラス出版委員会 (1982)] による主要な 地質断層を示す．これらは Fig. 3 のリニア メントと良い調和を示し，一般的にリニアメントが断裂の存在を反映していることを示唆する.

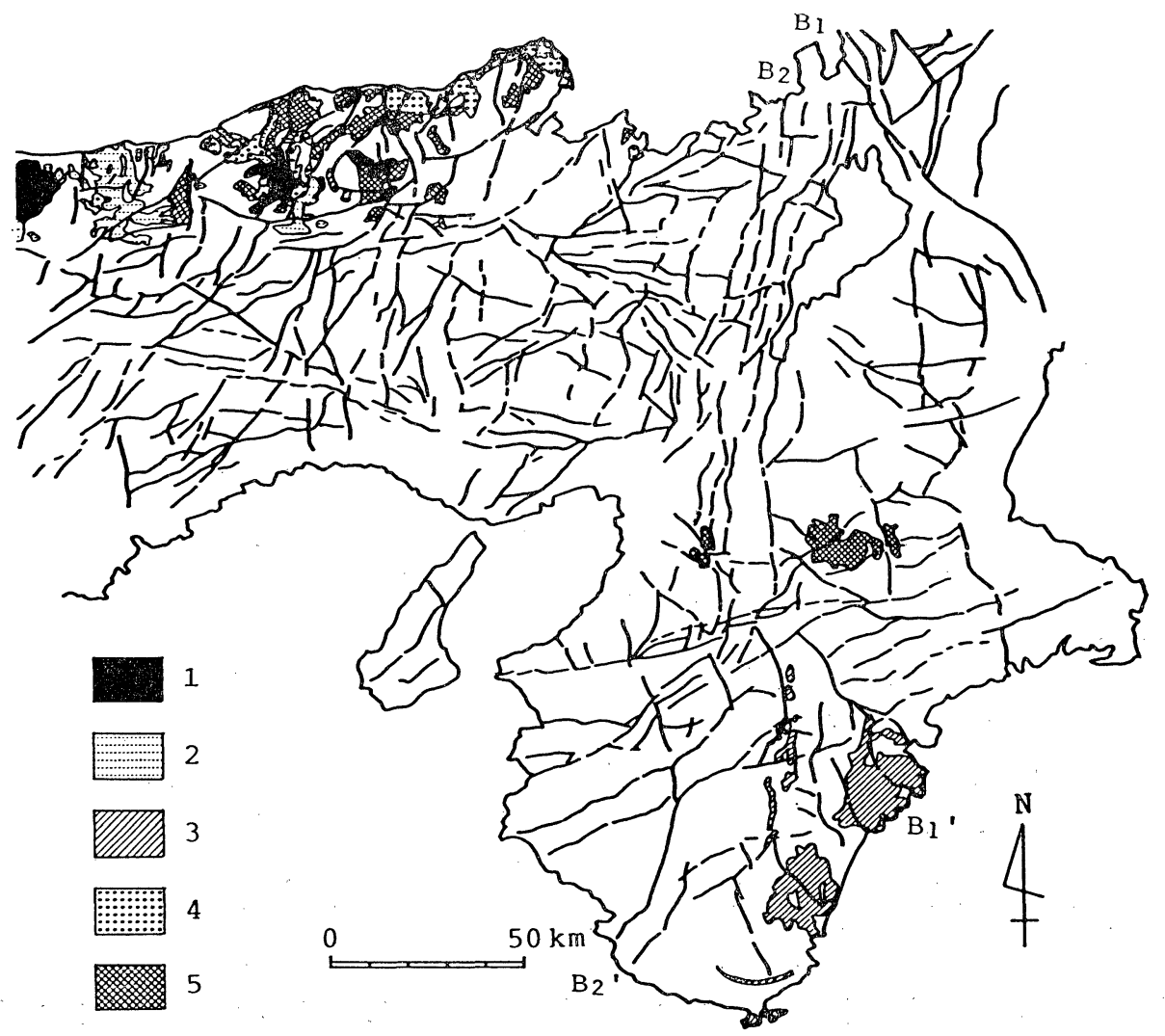

Fig. 5. Distribution of the Miocene to Holocene volcanoes, together with large scale lineaments in Fig. 3. 1: Late Pleistocene to Holocene volcanics, 2: Pliocene volcanics, 3: Miocene granites, 4: Middle to Late Miocene volcanics and 5: Early to Middle Miocene volcanics. 


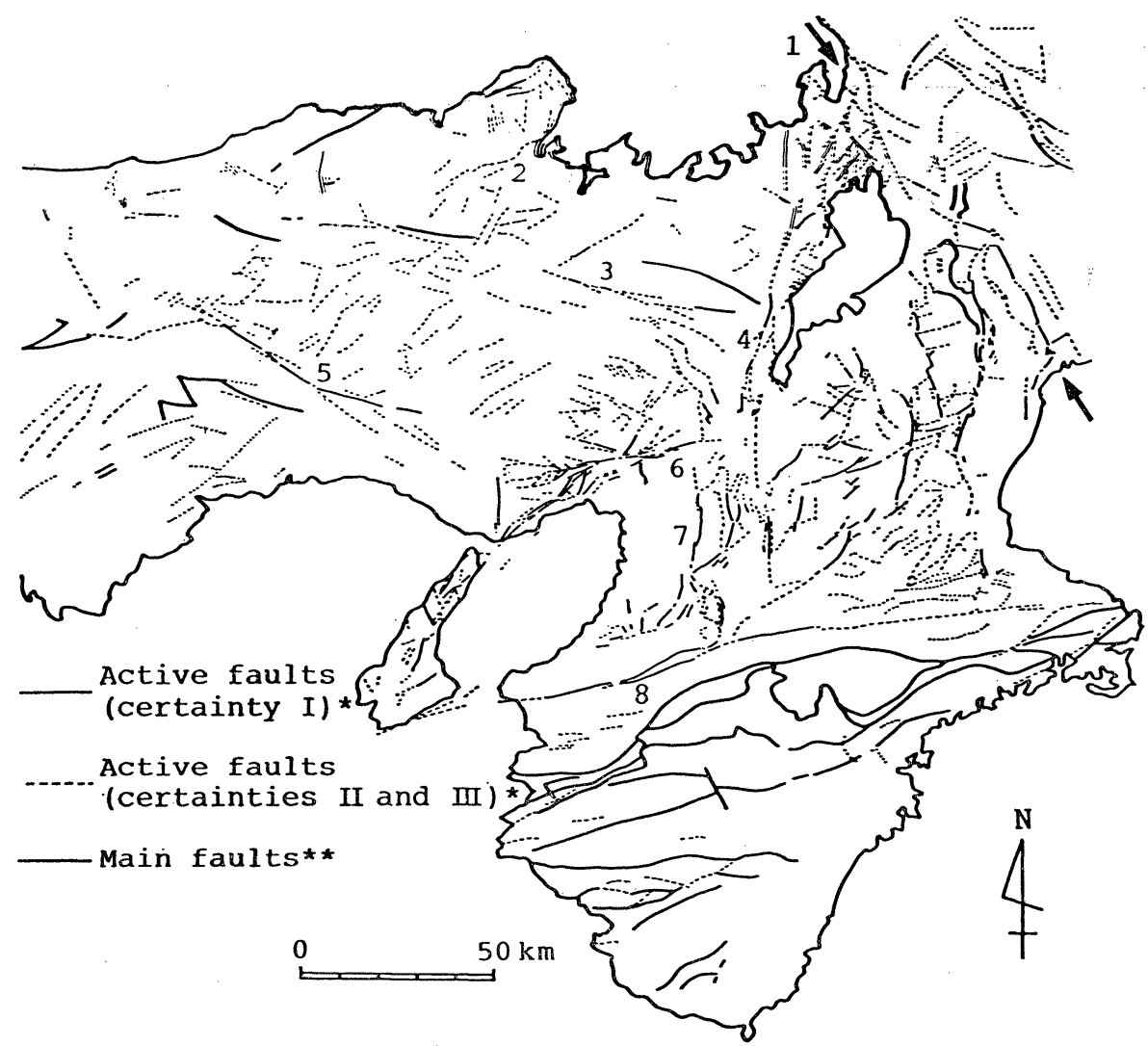

Fig. 6. Distribution of main faults. 1: Tsuruga-Ise Line, 2: Yamada F., 3: Mitoke F., 4: Hanaore F., 5: Yamasaki F., 6: Arima-Takatsuki Tectonic Line, 7: Ikoma F. and 8: Median Tectonic Line. * after The Res. Group for Active Faults (1980), and ** after Geol. Surv. of Japan (1982).

(1)の地域の地質断層は大まかには地層の走向に沿う逆断層性のもので，ほぼ ENE-WSW の走向をるつているが，それらの中には必ずしも完全にリニアメントに合致しないものもある. しかし，これまで断層としてほとんど記載されていない $\mathrm{N}-\mathrm{S}$ 系のものが多くリニアメントに 現れて和り，これらの中には断層と一致するものもあろう。また，(2)よび(3)の地域の活断層 は，リニアメントと良い調和を示し，リニアメントが断裂の存在を反映していることを示唆す る. したがつて，リニアメントのすべてが断層と一致するわけではないが，リニアメント分布 は断層の存在を予測する便利な手法の一つと考光られ, さらに詳細な断層調査を行うための基 礎資料となりうる。

\section{$\S 4 . \quad$ 近畿地方北西部地域の震央分布とリニアメント}

この地域の地震の観測は 1965 年から 20 年間以上にわたり行われているが，一方，地形は かなり長期間の地質構造運動の結果であるのでこれらが直接 $1: 1$ の対応をするとは考えられ ない.しかし，震央分布がリニアメンシの分布と良い一致を示すとすると，少なくとも観測さ 


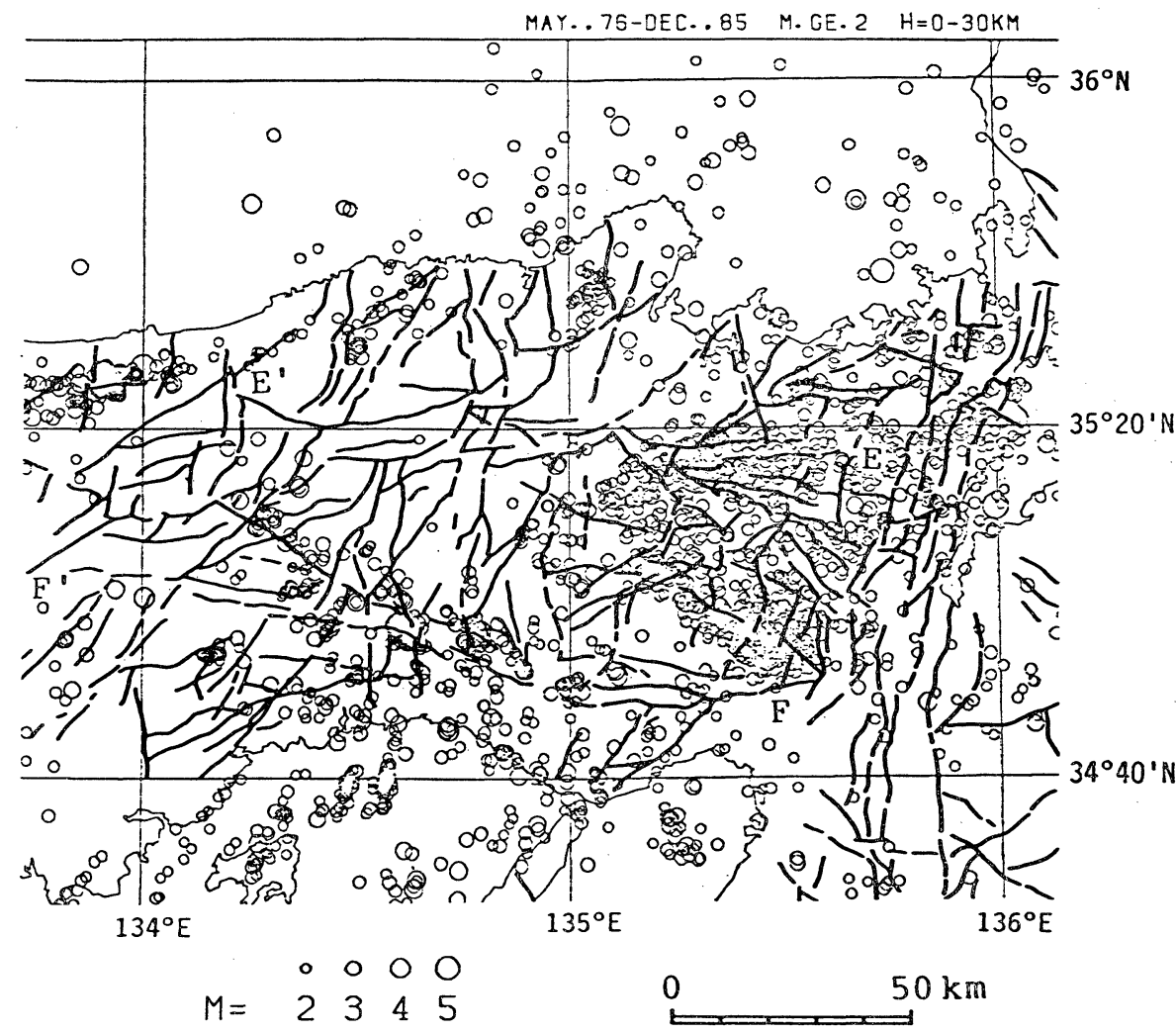

Fig. 7. Distribution of epicenters, together with large scale lineaments in Fig. 3.

れた時期にはリニアメントに示されるような断裂が活動的であつたことがわかるであろら.

Fig. 7 には 1976 1985 年の間に京都大学防災研究所 および 阿武山地震観測所によつて観 測された本地域の M2 以上の震央分布が示してある. この地域で地震の数の多い場所はリニ アメントの集中している $\mathrm{E} \sim \mathrm{E}^{\prime}$ より北側の WNW-ESE に延びる短冊状の地塊と F〜 F' の 南側の地区である. 中央の標高の高い地塊中では, 東部の淀川北西岸から琵琶湖西部にかけて の東側の N-S 系と北側の NE-SW 系および南側の NW-SE 系のリニアメントに囲をれた 地域に非常に多数の地震が発生している. これは, 後述するよらに, N-S 系のリニアメント に境される東側の地塊が，近畿地方北西部の地塊を西向きに押したと考えると，NW-SE 系 と NE-SW 系のリニアメントは共役的な割れ目と考えることができる. F F の活断層群と一致するものであり，前述の中央高地と南側低地の地塊との境界にあたる，これ に沿つて多数の震央が並ぶことは興味ある事実である.

\section{$\S 5$. 近畿地方北西部地域のリニアメントから推定される応力場}

本地域に観察される延長の長いリニアメントは $\mathrm{N}-\mathrm{S}$ 系と $\mathrm{E}-\mathrm{W}$ 系のものであるが，これ らはいずれも急斜面をもつた山地に沿って分布し, 山地の両側の低地との境界部に有力なるの が観察される. N-S 系のものとしては, (2)の地域の伊吹山地, 鈴鹿山脈, および比良, 生駒, 
金剛山地等に沿うものが代表的なもので, これらの山地の中間には同方向に延びる低地を伴つ ている. 例えば，上記山地の中間には琵琶湖から奈良盆地につながる細長い低地帯がある. $\mathrm{E}-\mathrm{W}$ 系のものとしては(3)の地域の $\mathrm{E} \sim \mathrm{E}^{\prime}$ と $\mathrm{F} \sim \mathrm{F}^{\prime}$ が大きいものであり，これらで境され る3つのブロックのうち中央のものが標高が高い. いずれのブロックも $20 \sim 40 \mathrm{~km}$ の幅をも つている.すなわち, 近畿地方の地殼は南北または東西方向に延びた幅 $20 \sim 40 \mathrm{~km}$ の短冊状 のブロックに区分され，その境界の断裂はその 延長が $100 \mathrm{~km}$ 以上あることからかなり深部 に達していると考えることができる．これはブロックの延長方向に直角な方向の圧縮力によつ て地殼が撓んだ結果短冊状に割れたもので各ブロックは交互に上昇または沈降をして山地と盆 地（低地）の繰り返しが形成されたと考えることができる.

藤田 (1980) は, 接峰面図から, 中部一近畿地方の山地が N-S ないし NNE-SSW 方向の 軸をるつ $50 \mathrm{~km}$ 波長の起伏を示すことを指摘し，その原因を第四紀の東西圧縮応力に求めて いる. また，NISHIDA (1973) は震源のメカニズムにより近畿地方の圧縮応力の軸は東西方向 であるとしている，すなわち，少なくとも第四紀当初より現在までの近畿地方に和ける地款応 力は東西方向にあると考它られている.

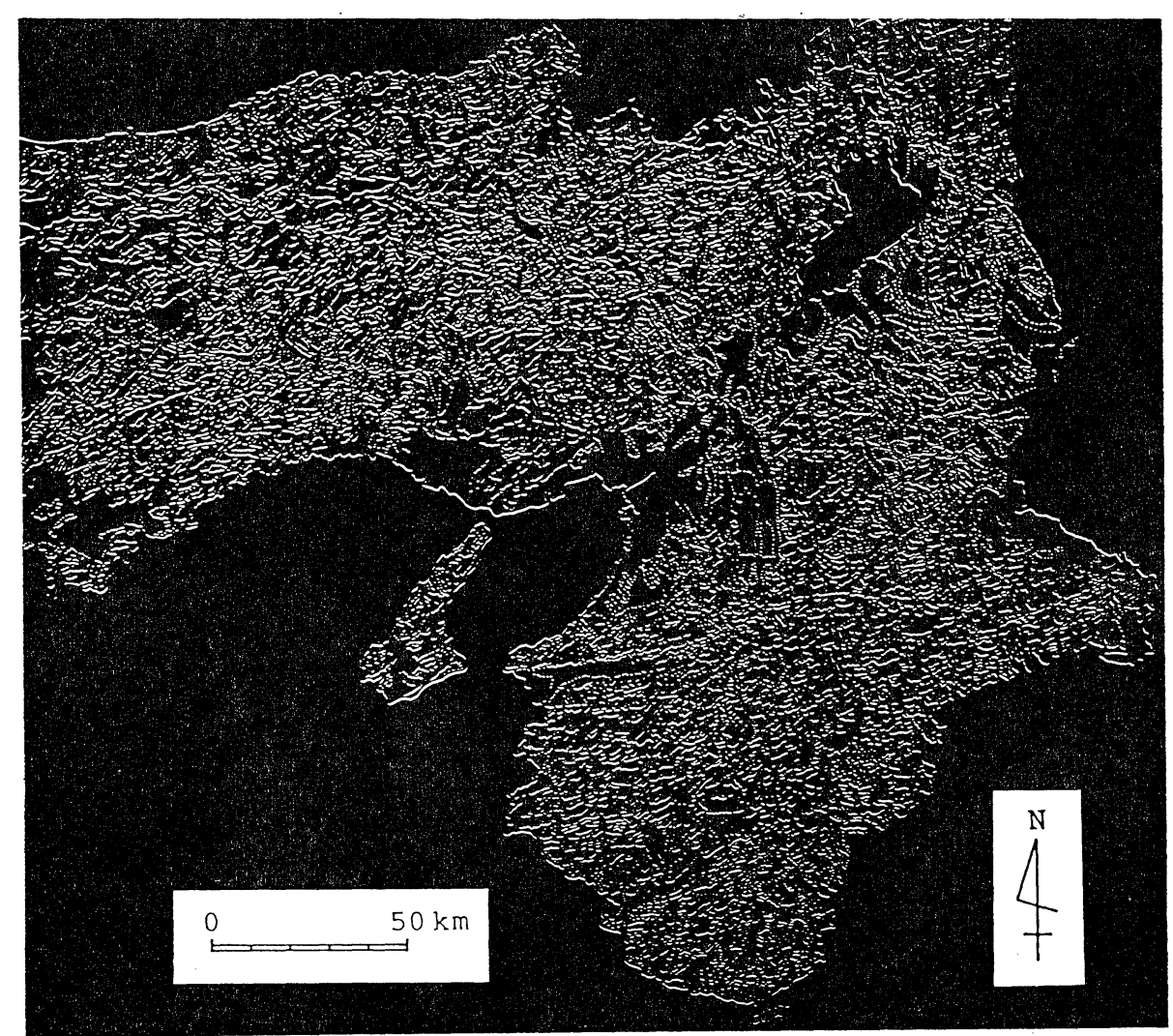

Fig. 8. Lineaments detected from overlapping and slightly shifting Fig. 1 and its negative figure. Small scale E-W lineaments showing many short valleys are included in this figure. 


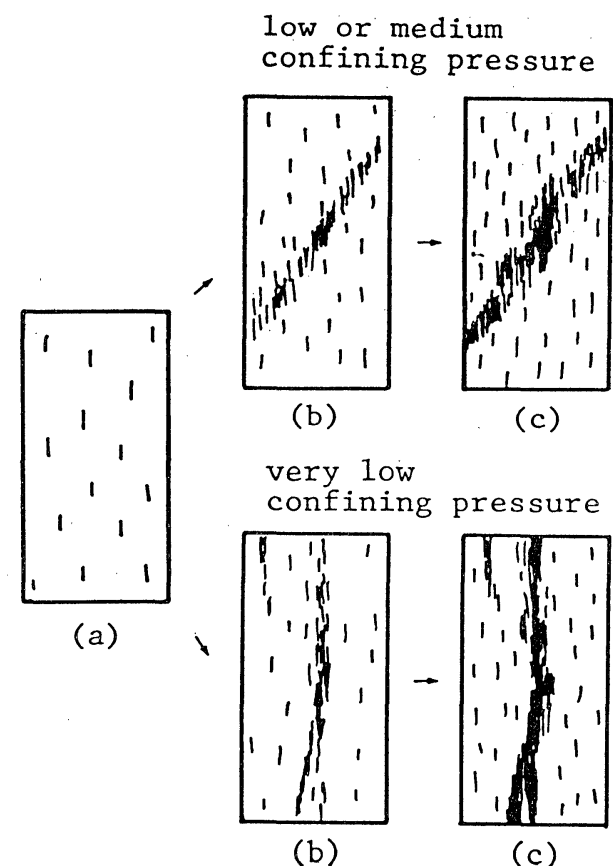

Fig. 9. Schematic representation of fracture development in rock specimen under different stress levels (a) to (c) of compression. Axis of the compression is vertical in this figure.
しかし, 近畿北西部の東西走向の起 状を生じさせるためには南北方向の応 力を考光る必要がある.これについて は, 第四紀以前には, 近畿地方は南北 方向の応力場にあつた証拠が指摘され ている [MINo (1984)].このことは， 山崎断層系に対応する $\mathrm{E} \sim \mathrm{E}^{\prime} p \mathrm{~F} \sim$ $\mathrm{F}^{\prime}$ は南北圧縮の時代に 形成された古 い断裂でありこのような断裂が第四 紀以降の東西方向の圧縮によつて横ず れを起こして，活動的な断裂となつて いると考光ることができる，ただし， 北西部地区には $\mathrm{E}-\mathrm{W}$ 执よび NESW, NW-SE の 3 方向の細かい断裂 が明瞭にまた多数見られるが，それら は，この地塊がより新期の東西圧縮に よつて新たに破壞されていることを推 測させる.

ここで，Fig. 1 と同図の 陰画を重 ね合わせて，片方の図を $\mathrm{NE}$ 方向に 少しずらして作成した図を Fig. 8 と 示す. 同図には非常に多数の $\mathrm{E}-\mathrm{W}$ 拉

よび ENE-WSW 方向の直線的な細かいリニアメントが現れる．これは，画面をずらすこと によつて，直線的な小さな谷の規則的な分布が強調されるようになつたものである．両図の場 合， 数多くの細かいリニアメントについては，どのようなずらしかたをしても $\mathrm{E}-\mathrm{W}$ のもの が他の方向のものに比べてはるかに明瞭である. このような，E-W 系の細かいリニアメント の成因に関しては，岩石の圧縮試験の結果生じる規則的な割れ目と対応させることによつて， それが生じた応力状態を推定することができる [向山・他 (1986)].

Fig. 9 は，各種の応力状態での割れ目の発生状況を封圧の大きさを考慮して 模式的に示し ている，ただし，封圧の大きさが小〜中程度で形成される共役性のせん断割れ目については， 同図中に一方向の割れ目のみを示している，また，各ブロック内に見られる $\mathrm{E}-\mathrm{W}$ 系の細かい リニアメントは, 非常に小さな封圧下で生じた引張り割れ目に相当すると考㝋ても良いと思わ れる。このような考方方をすれば，近畿地方の地殼に作用した第四紀以降の力は東西压縮応力 となる。

Fig. 3 に示したように NW-SE 特よび NE-SW 系のリニアメントは比良山地の西部にと くに多数発達していて, 活断層と一致することも多く，また，この地区に地震も多発している. したがつて，これらのリニアメントの大部分は，完新世にも活動している断裂を示すと思われ る.これらは，和そらく $\mathrm{E}-\mathrm{W}$ 系りニアメント形成と同様に東西圧縮応力によつて発達した第 三紀後期〜第四紀の断裂を表しているものと考えることができる．このようなリニアメントは 
共役性のせん断割れ目と考えられ，それができるためには，ある程度の N-S 方向からの拘束 カが必要である.

\section{§6. まとめ}

ランドサットを中心とする小縮尺の画像から作成された斜面強調図によるリニアメントの配 列は，本地域内で知られている地質断層や活断層の分布と良い調和を示すところが多い．した がつて，このような地形解析は，断層の存在を予測する便利な方法であると考えられる．それ と共に, リニアメントの配列は本地域に発達する広域的な断裂系の研究に有力な手段であるこ とも明らかとなつた。

今回示したリニアメントの発達状況から近畿地方は大別して 3 つ地塊に区分することがで きる、すなわち，(1)E-W 系ないし ENE-WSW 系とこれを横切る N-S 系のリニアメント によつて特徵づけられる中央構造線以南の紀伊半島と, (2)これに北接する N-S 系和よび E$\mathrm{W}$ 系に代表される花折-生駒断層, 中央構造線, 敦賀湾一伊勢湾に囲まれる地域, (3)E-W, NE-SW, NW-SE 系のリニアメントの発達が著しい花折断層以西の地域である.

(1), (2)の地域では, N-S 系のリニアメントは南北に伸びる山地またはその中間にある細長 い低地と平行であり，また，(3の地域の $\mathrm{E}-\mathrm{W}$ 系のリニアメントは同方向に伸びる山地とその 両側の低地の境界部に特に発達する，これは，本地方が東西または南北方向に圧縮され，地殼 がやや褶曲し，これに直角に延びる背斜部の山地と向斜部の低地になると共に，これらの境に 断裂が生じたとすれば，リニアメントはこれらの断裂を表しているものと考光られる.

(3の地域は他の地区に比べ， NW-SE， NE-SW 和よび E-W 系の細かいリニアメントの 発達が顕著であり, この配列は, 岩石の圧縮試験に現れる割れ目系の発達状況に酷似している.

1976 年から 10 年間に近畿地方北西部地域で観測された地震の震源分布はほぼ E-W 方向 に伸びる山地の両側に濃集し, 特に山地の南側のリニアメントに沿つて良く並んでいる. しか し, 山地の中には東側の一部を除いて震源の数が少ない.山地の東側では共役と考えられる $\mathrm{NW}-\mathrm{SE}$ 系と NE-SW 系, および(3)と(1)との地塊の境界にある N-S 系のリニアメントに囲 まれた三角形の地域に震源が濃集している. このことも, (3)の地域の地壳中に発生している東 西圧縮による割れ目を示していると考光ることができる.

東西圧縮応力の存在を推定させる E-W， NW-SE 扣よび NE-SW 系の細かい断裂は，大 部分の N-S 系断裂よりも新しく形成されたものであると考劣ることができる.

このような広域的な地形と地質の情報とを組み合わせて研究を行らりモートセンシングの手 法は広い地域の地質情報を短期間に検討することがでさる，今回は，近畿地方に働いている応 力の検討も行つたが，現在も働いている東西圧縮力が規則的な割れ目（活断層）の形成に重大 な関連をもつているので，この方向に延びるリニアメントに示される場所には活断層が今後も 見出される可能性がある.

\section{謝 辞}

本研究に使用したランドサット画像の一部は宇宙開発事業団より提供されたものである. 近 畿北西部地域の震央分布図は京都大学防災研究所より提供をうけた。ここに記して謝意を表す

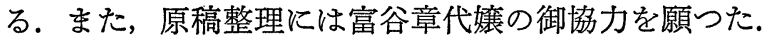




\section{文献}

地質アトラス出版委員会, 1982 , 日本地質アトラス, 地質調査所.

藤田和夫, 1980, 中部・近畿北部の第四紀テクトニクスと造構応力場. 月刊地球, 2, 586-595.

活断層研究会編, 1980, 日本の活断層, 東京大学出版会.

Mino, K., 1984, On the Formation Mechanism of Topography and its Relation to Earthquake Occurrence in Southwest Japan, Bull. Disas. Preven. Res. Inst., Kyoto Univ., 34, 130-167. 向山 広・木村 強・中村真人，1986，斜面強調図形によるリニアメントを利用した中部地方の地質 構造運動の解析. 地形, 7, 103-124.

日本放送出版協会, 1984, 地球観測衛星ランドサット日本列島地図帖, LANDSAT ATLAS: JAPAN. NishidA, R., 1973, Earthequake Generating Stress in Eastern District, Southwest Japan, Bull. Disas, Preven. Res. Inst., Kyoto Univ., 22, 197-233. 